\title{
Analisis Anteseden Perilaku Manajemen Finansial Pada Generasi Milenial di Indonesia
}

\author{
Aishuia (122011810004) \\ Project Management Institute Indonesia \\ aishuia@gmail.com \\ Kusnul Fitriani (122011810042) \\ Eni Muara Bakau B.V. \\ kusnul.fitriani@yahoo.com \\ Farah Margaretha Leon \\ Dosen FEB Universitas Trisakti, Indonesia \\ farahmargaretha@trisakti.ac.id
}

\begin{abstract}
Millennial generation is identified as materialism, likes credit card promotions, lacks unrealistic knowledge and optimism about the ability to repay debts and has a lifestyle around spending, which follows a "spend now" and "pay later" pattern, and as a consequence, they have a higher tendency towards loan products. The purpose of this study is to determine whether the factors of financial knowledge, behavior of seeking assistance, electronic banking have an influence on the behavior of millennial generation financial management in Indonesia. The sampling method uses convenience sampling. The analysis technique used in this research is Explotary Factor Analysis (EFA) processed using SPSS then Confirmatory Factory Analysis (CFA) and Structural Equation Modeling (SEM) processed using Analysis of Moments Structures (AMOS). The results showed that there was a significant influence on the behavior of seeking assistance and electronic banking on the behavior of millennial generation financial management in Indonesia, otherwise the financial knowledge variable did not affect financial knowledge. This research is useful: for practitioners in the field of finance can take advantage in the utilization of technological aspects (electronic banking) to improve financial management behavior. For financial managers able to focus on various investment and financing decisions, as well as all matters related to it. For investors to reduce the behavior of lack of responsibility in financial management.
\end{abstract}

Keywords: banking electronics; millennial generation; financial knowledge; financial management behavior; seeking help behavior.

\section{PENDAHULUAN}

Generasi milenial memiliki peranan yang penting di dalam perekonomian suatu negara karena generasi ini memiliki potensial aliran pendapatan dalam suatu bisnis. Generasi milenial dikenal sebagai "Generation Y", "Next Generation", "Generation Me", dan berbagai istilah lainnya, yang merupakan generasi yang lahir antara tahun 1980 dan 2000. Dan untuk saat ini, generasi milenial merupakan generasi terbesar dengan usia dewasa muda yang memasuki dunia kerja dibandingkan dengan generasi sebelumnya (Sharon, 2015) (Mulyana, Soeaidy, \& Taufiq, 2019).

Karakteristik dari generasi milenial berbeda dengan generasi X, generasi Baby Boomers, ataupun generasi lainnya. Generasi ini di identifikasi sebagai materialisme, menyukai promosi kartu kredit, kurang memiliki pengetahuan dan optimisme yang tidak realistik mengenai kemampuan untuk pembayaran hutang serta peraturan yang kurang efektif. Dan juga memiliki gaya hidup di 
seputar pengeluaran, yang mengikuti pola "spend now" dan "pay later", dan sebagai konsekuensi, mereka memiliki kecenderungan yang lebih tinggi terhadap produk-produk pinjaman. (Bapat, 2019). Dengan gaya hidup dan karakteristik ini, penulis tertarik untuk membuat suatu penelitian mengenai perilaku manajemen finansial di Indonesia.

\section{TINJAUAN PUSTAKA}

\section{Kerangka Konseptual}

Pengetahuan keuangan adalah penggabungan dari kemampuan, perilaku, kesadaran, sikap dan pengetahuan dari individu yang diperlukan untuk membuat keputusan finansial yang menuju pencapaian kesejahteraan keuangan (Rai, Dua, \& Yadav, 2019). Meskipun literasi keuangan terkait pada karakteristik sosiodemografis dan keuangan keluarga yang berpengalaman, ternyata observasi menunjukkan rendahnya literasi keuangan di antara kalangan anak muda (Bapat, 2019). Grimes, Rogers, dan Smith (2010) menginvestigasi pengetahuan keuangan di antara berbagai segmen konsumen dan menemukan adanya kaitan positif antara tingkat pendidikan dan perbankan. Suatu kajian oleh Asaad (2015) mengemukakan bahwa pengetahuan keuangan, mempengaruhi keputusan keuangan. Literasi keuangan, program pendidikan dan seminar yang melibatkan tabungan dan kekayaan finansial dapat memainkan peran penting dalam membantu orang - orang untuk mengembangkan kebiasaan pengaturan keuangan yang bertanggung jawab.

Perilaku mencari bantuan mempengaruhi pengambilan keputusan yang terkait dengan kesehatan. Peneliti sebelumnya mengeksplorasi peranan dari perilaku mencari bantuan, yang mana dipertimbangkan sebagai strategi untuk mengatasi masalah finansial, yang terdiri dari lima tahap: perilaku keuangan, evaluasi dari perilaku keuangan pribadi, identifikasi penyebab perilaku keuangan, keputusan mencari pertolongan dan pemilihan dari opsi - opsi pendampingan bantuan. Dan ditemukan bahwa perilaku mencari bantuan mempengaruhi perilaku manajemen keuangan (Bapat, 2019).

Elektronik perbankan terkait pada penyediaan informasi dan layanan terhadap konsumen melalui komputer atau televisi. Ada perubahan-perubahan yang penting yang diamati dalam bagaimana cara electronik banking dilakukan. Penemuan ini mengkonfirmasi bahwa rasio pengguna dari kalangan anak muda lebih tinggi untuk Automated Teller Machines dan mereka lebih nyaman dalam penggunaan elektronik perbankan. Dari analisa terdahulu menunjukkan bahwa pengguna elektronik perbankan lebih muda daripada pengguna non elektronik perbankan (Bapat, 2019). Berdasarkan penjelasan di atas, maka dapat dibentuk kerangka konseptual sebagai berikut:

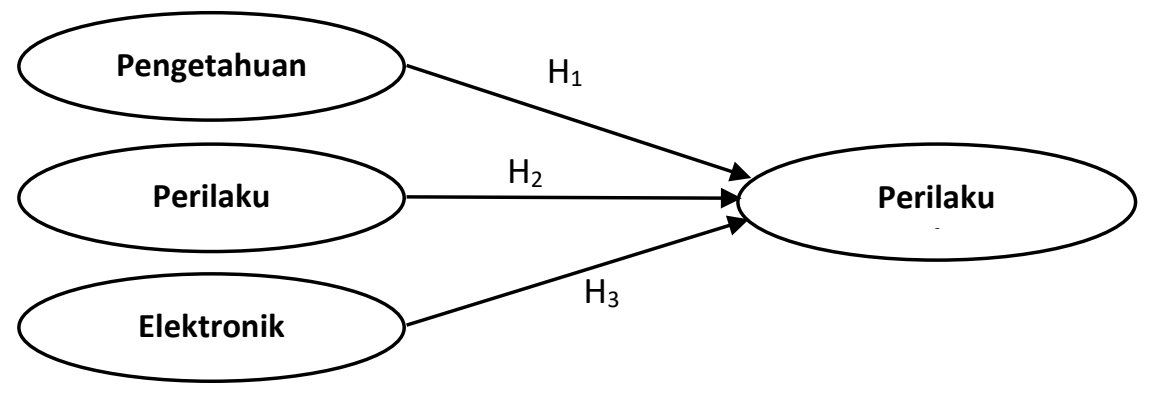

Gambar 1 Kerangka konseptual 


\section{Pengembangan Hipotesa}

Pengetahuan tentang keuangan merujuk pada pengertian akan keuangan dan kemampuan untuk mengutilisasi untuk membuat keputusan keuangan pribadi yang baik (Sundarasen, Rahman, Othman, \& Danaraj, 2016). Pengetahuan keuangan pribadi telah dinilai di berbagai negara dan disetujui apabila orang-orang yang kekurangan pengetahuan tentang keuangan untuk menggunakan informasi baru yang disediakan untuk mereka di era baru yang mana informasi dibagikan secara terbuka. Generasi Y atau generasi Milenial sudah harus membuat keputusan penting sejak dini, seperti melanjutkan pendidikan, membeli kendaraan, dan perumahan yang merupakan hal yang sangat penting untuk keuangan masa depan mereka (Killins, 2017). Orang yang berpendidikan dan berpengalaman sering mengalami kesulitan dalam menangani beban utang dan melunasi pinjaman tepat waktu. Penggunaan uang secara bertanggung jawab biasanya akan mendapatkan lebih banyak perhatian dari individu-individu dengan penghasilan tetap. Seseorang yang berpenghasilan rendah cenderung tidak tepat waktu untuk membayar tagihan. Hal ini berkaitan dengan perilaku manajemen keuangan yang menunjukkan penggunaan uang oleh seseorang yang bertanggung jawab mewakili kebiasaan manajemen keuangannya (Amalia Nusron, Wahidiyah, \& Setyo Budiarto, 2018). Masyarakat dapat dikatakan memiliki pengetahuan keuangan yang tinggi apabila sudah bisa menghargai uang, mengelola perencanaan keuangannya dan sudah bisa merencanakan keuangannya untuk masa depan. Yang menyebabkan masyarakat Indonesia masih kurang pengetahuannya terhadap literasi keuangan adalah masih kurangnya pengetahuan dan pencarian informasi mengenai tabungan atau investasi pada lembaga keuangan, baik di bank ataupun asuransi serta kurang pahamnya mengenai manfaat tabungan atau asuransi tersebut (Rasuma Putri \& Rahyuda, 2017). Teori pembelajaran digunakan untuk membantu seseorang dalam mengubah perilaku keuangan kesehariannya yang diperoleh dari hasil belajar selama hidupnya. Dimana dalam perubahan perilaku keuangan itu dipengaruhi oleh literasi keuangan. Yang mana literasi keuangan tersebut memberikan keahlian dan kemampuan bagi seseorang dalam mengelola keuangan pribadi dengan bekal pengetahuan yang dimiliki. Pembelajaran di perguruan tinggi memiliki peranan penting dalam membentuk perilaku keuangan mahasiswa. Dimana dalam pembelajaran yang dilakukan seseorang memperoleh ilmu pengetahuan yang kemudian bisa dipraktekkan pada perilaku sehari-hari (Erawati, 2016).

Berdasarkan penjelasan di atas maka dirumuskan hipotesis sebagai berikut:

\section{H1: Pengetahuan keuangan positif mempengaruhi perilaku manajemen finansial.}

Perilaku mencari bantuan mempengaruhi pada pengambilan keputusan yang terkait dengan kesehatan dan mempengaruhi perilaku manajemen keuangan (Bapat, 2019). Proses pencarian bantuan keuangan terdiri dari lima tahap: (1) pameran perilaku keuangan, (2) evaluasi perilaku keuangan sendiri, (3) identifikasi penyebab perilaku keuangan, (4) keputusan untuk mencari bantuan, dan (5) pilihan di antara opsi-opsi bantuan (Lim, Heckman, Letkiewicz, \& Montalto, 2014). Mencari nasihat keuangan dianggap sebagai perilaku keuangan yang diinginkan, yang merupakan komponen dari kemampuan keuangan konsumen (Bapat, 2019). Nasihat investasi telah menunjukkan faktor penting dalam membentuk portofolio klien. Foerster et al (2014) menemukan bahwa penasihat mendorong klien untuk mengambil risiko lebih besar tanpa premi ekuitas terkait setelah mengendalikan biaya. Di sisi lain, saran investasi terkait dengan tingkat 
volatilitas portofolio yang lebih rendah (Porto, 2014). Perencanaan keuangan profesional adalah pilihan penting untuk kesejahteraan finansial secara keseluruhan. Perencana keuangan memiliki alat dan keahlian yang kurang dalam populasi umum. Manfaat perencanaan keuangan profesional membantu beragam komponen perencanaan keuangan. Ada enam bidang luas: perencanaan pajak, perencanaan arus kas, investasi, manajemen risiko, perencanaan pensiun, dan perencanaan perkebunan (Letkiewicz, Robinson, Domian, \& Uborceva, 2018).

Berdasarkan penjelasan di atas maka dirumuskan hipotesis sebagai berikut:

\section{H2: Perilaku mencari bantuan positif mempengaruhi perilaku manajemen finansial.}

Kemajuan teknologi di abad ke-20 telah sangat berdampak pada perubahan gaya hidup masyarakat. Perkembangan teknologi komunikasi dan informasi dalam bentuk media sosial juga telah membawa banyak dampak pada kehidupan sosial dan gaya hidup, terutama bagi generasi milenial (Mulyana et al., 2019). Keprihatinan atas kemajuan dalam elektronik perbankan yang tidak menghasikan kemajuan dalam perilaku manajemen keuangan merupakan suatu alasan yang menarik untuk mempelajari hubungan nya. Di mana beberapa bank telah menyediakan penawaran berbasis Internet sebagai fasilitas perencanaan keuangan, namun penggunaan layanan tersebut menghasilkan dampak yang terbatas terhadap perilaku manajemen keuangan di antara konsumen dari generasi Y (Bapat, 2019).

Lebih dari 50 persen dari semua orang Amerika memantau rekening bank pribadi mereka menggunakan aplikasi atau situs seluler yang disediakan oleh lembaga perbankan mereka (Federal Reserve Board, 2016), dan sebagian besar laporan industri fokus pada fitur-fitur fungsional yang seharusnya dimiliki oleh aplikasi perbankan seluler, termasuk pembayaran tagihan transfer internasional dan pembayaran peer-to-peer (Bayuk \& Altobello, 2019). Pada kenyataannya, sebagian besar layanan mobile banking tidak dirancang untuk menjadi menyenangkan atau menghibur, hanya transaksional, namun konsumen memiliki niat lebih tinggi untuk menggunakan aplikasi perbankan jika elemen hedonis meningkatkan kesenangan dan kenikmatan lebih ditekankan (Baptista \& Oliveira, 2017).

Berdasarkan penjelasan di atas maka dirumuskan hipotesis sebagai berikut:

\section{H3: Elektronik perbankan positif mempengaruhi perilaku manajemen finansial.}

\section{METODE PENELITIAN}

Dalam penelitian ini desain yang digunakan yaitu Penelitian Kausal. Penelitian Kausal merupakan penelitian yang mengetahui pengaruh antara satu atau lebih variabel bebas (independent variable) terhadap variabel terikat (dependent variable).

\section{Metode pengambilan Sampel}

Minimal sampel dalam penelitian ini adalah 120 sampel tetapi untuk memperoleh data yang optimal maka 120 x2 jadi 240 sampel dan data yang dapat dikumpulkan 240 sampel . Sampel tersebut dari kota-kota di Indonesia. Kelompok usia responden berkisar antara 19 sampai 39 tahun dengan perbandingan jenis kelamin antara pria dan wanita yang seimbang. Pernyataan kuesioner terkait pada perilaku manajemen keuangan, perilaku mencari-bantuan, pengetahuan keuangan dan elektronik perbankan. 


\section{Metode Analisis Data}

\section{Analisis Deskriptif}

Menurut Sugiyono (2012), menjelaskan bahwa Penelitian deskriptif adalah penelitian yang dilakukan untuk mengetahui nilai variabel mandiri, baik satu variabel atau lebih (independen) tanpa membuat perbandingan atau menghubungkan antara satu dengan variabel yang lain.

Teknik analisis yang digunakan dalam penelitian ini adalah Explotary Factor Analysis (EFA) diolah menggunakan SPSS versi 22 kemudian Confirmatory Factory Analysis (CFA) dan Structural Equation Modeling (SEM) diolah menggunakan Analysis of Moments Structures (AMOS) versi 24. Untuk menguji keandalan dari validitas konstruk menggunakan Analysis of Moments Structures (AMOS) versi 24. Untuk memverifikasi faktor-faktor dari empat variabel menggunakan Confirmatory Factory Analysis (CFA). Untuk mengukur asosiasi variabel independen dengan variabel dependen menggunakan Structural Equation Modeling (SEM) melalui uji kelayakan keseluruhan (Model Fit). Hal tersebut menunjukan bahwa model mampu memprediksi nilai observasinya atau dapat dikatakan model diterima karena sesuai dengan data observasinya (Ghozali, 2011).

\section{Identifikasi dan pengukuran Variabel}

Variabel Dependen: Perilaku Manajemen Keuangan.

Variabel Independen: Pengetahuan Keuangan, Perilaku Mencari Bantuan, dan Elektronik Perbankan.

Pengukuran dari tiap pertanyaan menggunakan skala likert. Empat kategori jawaban yang dimulai dari strongly disagree hingga strongly agree digunakan untuk kuesioner. Menurut Sugiyono (2013) Skala likert berguna untuk menilai pendapat dan pandangan individu atau sekelompok masyarakat mengenai fenomena indikator yang sudah ditetapkan variabel penelitianya. Setelah itu indeks ditetapkan sebagai titik pangkal agar dapat merumuskan point instrument yang terdapat beberapa pernyataan maupun pertanyaan. Jawaban setiap poin instrument memiliki tingkatan dari sangat positif sampai negative yang dapat berupa kata antara lain :
a) Sangat setuju (SS) : skor 4
b) Setuju (S) : Skor 3
c) Tidak setuju (TS) :Skor 2
d) Sangat tidak setuju (STS) : Skor 1

\section{Tabel 1}

Variabel dan Pengukuran

\begin{tabular}{|l|l|l|l|l|l|}
\hline No & Variabel & Construct & Mean & Kode & Indikator \\
\hline 1. & $\begin{array}{l}\text { Variabel } \\
\text { Dependen } \\
(\text { Y) }\end{array}$ & $\begin{array}{l}\text { Perilaku } \\
\text { Manajemen } \\
\text { Keuangan } \\
\text { (PMK) }\end{array}$ & 3,0 & PMK1 & $\begin{array}{l}\text { Saya akan mengikut } \\
\text { anggaran bulanan } \\
\text { dengan hati-hati }\end{array}$ \\
\cline { 3 - 6 } & 3,4 & PMK2 & $\begin{array}{l}\text { Saya menabung atau } \\
\text { menyisihkan uang } \\
\text { secara rutin untuk } \\
\text { masa depan }\end{array}$ \\
\hline
\end{tabular}




\begin{tabular}{|c|c|c|c|c|c|}
\hline & & & & PMK3 & $\begin{array}{l}\text { Saya melakukan } \\
\text { perencanaan } \\
\text { keuangan untuk } \\
\text { masa depan }\end{array}$ \\
\hline & & & & PMK4 & $\begin{array}{lr}\text { Saya } & \text { rutin } \\
\text { melakukan } & \\
\text { pencatatan mengenai } \\
\text { pemasukan } \\
\text { pengeluaran dan } \\
\text { saya }\end{array}$ \\
\hline & & & 3,1 & PMK5 & $\begin{array}{l}\text { Saya memiliki dana } \\
\text { cadangan untuk masa } \\
\text { depan ketika terjadi } \\
\text { resesi ekonomi }\end{array}$ \\
\hline 2. & $\begin{array}{l}\text { Variabel } \\
\text { Independen } \\
(\mathrm{X})\end{array}$ & $\begin{array}{l}\text { Elektronik } \\
\text { Perbankan } \\
\text { (EP) }\end{array}$ & 2,9 & EP1 & $\begin{array}{l}\text { Pembayaran } \\
\text { elektronik (misalnya } \\
\text { pembayaran dengan } \\
\text { kartu debit, kartu } \\
\text { kredit, internet } \\
\text { banking, mobile } \\
\text { banking ds) } \\
\text { memotivasi saya } \\
\text { untuk bertransaksi di } \\
\text { perbankan }\end{array}$ \\
\hline & & & 3,1 & EP2 & $\begin{array}{l}\text { Lebih mudah atau } \\
\text { nyaman untuk } \\
\text { melakukan Internet } \\
\text { banking }\end{array}$ \\
\hline & & & 3,1 & EP3 & $\begin{array}{l}\text { Mobile banking } \\
\text { lebih menarik }\end{array}$ \\
\hline & & $\begin{array}{l}\text { Perilaku } \\
\text { Mencari } \\
\text { Bantuan (PMB) }\end{array}$ & 3,3 & PMB1 & $\begin{array}{l}\text { Saya akan mencari } \\
\text { nasihat dari teman- } \\
\text { teman sebelum saya } \\
\text { berinvestasi }\end{array}$ \\
\hline & & & 3,2 & PMB2 & $\begin{array}{lr}\text { Saya akan } & \text { mencari } \\
\text { nasihat } & \text { dari } \\
\text { konsultan } & \text { finansial } \\
\text { sebelum } & \text { saya } \\
\text { berinvestasi. } & \end{array}$ \\
\hline & & $\begin{array}{l}\text { Pengetahuan } \\
\text { Keuangan (PK) }\end{array}$ & 2,6 & PK1 & $\begin{array}{lr}\text { Deposito } & \text { tetap } \\
\text { dengan } & \text { bank } \\
\text { komersial adalah } & \text { bebas resiko }\end{array}$ \\
\hline & & & 2,9 & PK2 & $\begin{array}{l}\text { Inflasi menurunkan } \\
\text { kemampuan daya } \\
\text { beli saya. }\end{array}$ \\
\hline
\end{tabular}

Sumber : Data dari peneliti 


\section{HASIL PENELITIAN DAN PEMBAHASAN}

\section{Hasil Uji Instrumen Penelitian \\ Uji validitas}

Uji validitas dengan uji CFA atau tes konstruk validitas digunakan untuk melihat indikator apakah layak atau tidak menompang variabel laten. Indikator dikatakan valid apabila Criteria Ratio $(\mathrm{CR})>1,96$ dengan nilai probabilitas $(\mathrm{P})<0,05$ dengan demikian dapat disimpulkan bahwa semua instrument yaitu pengetahuan keuangan, perilaku mencari bantuan, elektronik perbankan dan perilaku manajemen keuangan validitasnya terpenuhi. Pengujian validitas dilakukan pada empat variabel dalam penelitian ini. Hasil uji validitas menunjukkan bahwa semua item pernyataan memiliki validitas yang baik.

\section{Tabel 2}

Tabel Validitas

\begin{tabular}{|c|c|c|c|c|}
\hline No & $\begin{array}{l}\text { Hipothesized } \\
\text { Model Parameter }\end{array}$ & C.R. & P Value & Level \\
\hline \multirow[t]{3}{*}{1.} & PMK -> PMK1 & & & \\
\hline & PMK -> PMK2 & 7.8 & 0,005 & Signifikan \\
\hline & PMK -> PMK5 & 7.8 & 0,005 & Signifikan \\
\hline \multirow[t]{3}{*}{2.} & EP - > EP1 & & & \\
\hline & EP -> EP2 & 8.9 & 0,005 & Signifikan \\
\hline & EP -> EP3 & 8.7 & 0,005 & Signifikan \\
\hline \multirow[t]{2}{*}{3.} & PMB -> PMB2 & & & \\
\hline & PMB -> PMB1 & 4.6 & 0,005 & Signifikan \\
\hline \multirow[t]{2}{*}{4.} & PK -> PK2 & & & \\
\hline & PK -> PK1 & 2.9 & 0,01 & Tidak Signifikan \\
\hline
\end{tabular}

Sumber : Data diolah peneliti tahun 2020 dengan program AMOS versi 24

\section{Uji Reliabilitas}

Uji reabilitas dengan uji konstruk reabilitas digunakan untuk melihat konsistensi data. Artinya apabila nilai dari konstruk reliabilitas $>0,5$ maka dikategorikan bahwa indikator dalam penelitian adalah tinggi atau baik. Berikut adalah hasil uji reliabilitas:

Tabel 3

Tabel Reliabilitas

\begin{tabular}{|l|l|l|l|}
\hline No. & Indikator & Reliabilitas & Level \\
\hline 1. & Perilaku Manajemen Keuangan (PMK) & 0,83 & Tinggi \\
\hline 2. & Elektronik Perbankan (EP) & 0,86 & Tinggi \\
\hline 3. & Perilaku Mencari Bantuan (PMB) & 0,82 & Tinggi \\
\hline 4. & Pengetahuan Keuangan (PK) & 0,42 & Rendah \\
\hline
\end{tabular}

Sumber : Data diolah peneliti tahun 2020 dengan program AMOS versi 24 
Berdasarkan tabel 3 diperoleh nilai konstruk reliabilitas PMK, EP, PMB $>0,5$ adalah tinggi dan bisa digunakan dalam penelitian, sedangkan nilai konstruk reliabilitas $\mathrm{PK}<0,5$ adalah rendah dan kurang baik digunakan dalam penelitian.

\section{Hasil Pengumpulan Data}

Pengumpulan data dalam penelitian ini menggunakan kuesioner. Metode pengumpulan sampel. Responden adalah generasi milenial di Indonesia yang berusia 19 - 39 tahun. Adapun hasil kuesioner adalah sebagai berikut:

Tabel 4

Hasil Pengumpulan Data

\begin{tabular}{|l|l|l|}
\hline Keterangan & Jumlah & Presentase \\
\hline Kuesioner Manual yang disebar & 146 & $60 \%$ \\
\hline Kuesioner Online yang disebar & 94 & $40 \%$ \\
\hline Kuesioner yang memenuhi syarat & 240 & $100 \%$ \\
\hline
\end{tabular}

Sumber : Data dari peneliti

\section{Hasil data responden}

Berdasarkan tabel 5 dapat disimpulkan bahwa Profil dari 240 responden generasi milenial di Indonesia menurut hasil data yaitu pria $=125$ responden dan wanita $=115$ responden. Usia $19-$ $25=143$ responden, usia $26-32=66$ responden, usia $33-39=31$ responden. Kota domisili dari Jakarta $=106$ responden, Bandung $=35$ responden, Surabaya $=49$ responden, Makasar $=35$ responden dan lainnya (jogja, jambi, bali, aceh, dll) $=105$ responden. Pekerjaan responden mulai dari PNS $=14$ responden, pegawai swasta $=77$ responden, wiraswasta $=18$ responden, Mahasiswa $=101$ responden, tidak bekerja $=8$ responden dan yang bekerja lainnya $=22$ responden. Untuk Pendidikan terakhir mulai dari $\mathrm{SD}=8$ responden, SMP $=1$ responden, $\mathrm{SMU} / \mathrm{SMK}=123$ responden, $\mathrm{S} 1=86$ responden, $\mathrm{S} 2=16$ responden, $\mathrm{S} 3=1$ responden, Bidang Pendidikan terakhir responden adalah Manajemen/Ekonomi/Bisnis/Akuntansi/Keuangan $=106$ responden, Pertanian/Peternakan/Kelautan $=4$ responden, Teknik $=32$ responden, Senirupa \& Desain $=9$ responden, dan bidang Pendidikan lainnya $=89$ responden .

\section{Tabel 5}

Demografik Responden berdasarkan Tipe pengguna

\begin{tabular}{|l|l|}
\hline Kategori & Jumlah \\
\hline Jenis Kelamin & \\
Pria & 125 \\
Wanita & 115 \\
\hline Usia & \\
$(19-25)$ & 143 \\
$(26-32)$ & 66 \\
$(33-39)$ & 31 \\
\hline
\end{tabular}




\begin{tabular}{|l|l|}
\hline Kota Domisili & \\
Jakarta & 106 \\
Bandung & 35 \\
Surabaya & 49 \\
Makasar & 35 \\
Lainnya & 5 \\
\hline Pekerjaan & \\
PNS & 14 \\
Pegawai Swasta & 77 \\
Wiraswasta & 18 \\
Mahasiswa & 101 \\
Tidak Bekerja & 8 \\
Lainnya & 22 \\
\hline Pendidikan Terakhir & \\
SD & 8 \\
SMP & 1 \\
SMU/SMK & 123 \\
S1 & 86 \\
S2 & 16 \\
S3 & 1 \\
Lainnya & 5 \\
\hline Bidang Pendidikan Terakhir & \\
Manajemen/Ekonomi/Bisnis/Akuntansi/Keuangan & 106 \\
Pertanian/ Peternakan/Kelautan & 4 \\
Teknik & 32 \\
Senirupa \& Desain & 9 \\
Lainnya & 89 \\
\hline
\end{tabular}

Sumber : Data dari peneliti

\section{Explotary Factor Analysis (EFA)}

EFA pertama kali dilakukan untuk mengeksplorasi seberapa baik pengukuran item memuat pada konstruksi tertentu dalam konteks khusus ini dan semua item dimuat dengan baik ke konstruk masing-masing. Hasil EFA menunjukkan bukti bahwa empat variabel yaitu: Perilaku manajemen keuangan (PMK), elektronik perbankan (EP), perilaku mencari bantuan (PMB) dan pengetahuan keuangan (PK) tidak memiliki korelasi.

\section{Confirmatory Factory Analysis (CFA) dan Structural Equation Modeling (SEM)}

Analisis model persamaan struktural secara penuh (full structural equation model analysis) dapat dilihat pada gambar 2 sebagai berikut: 


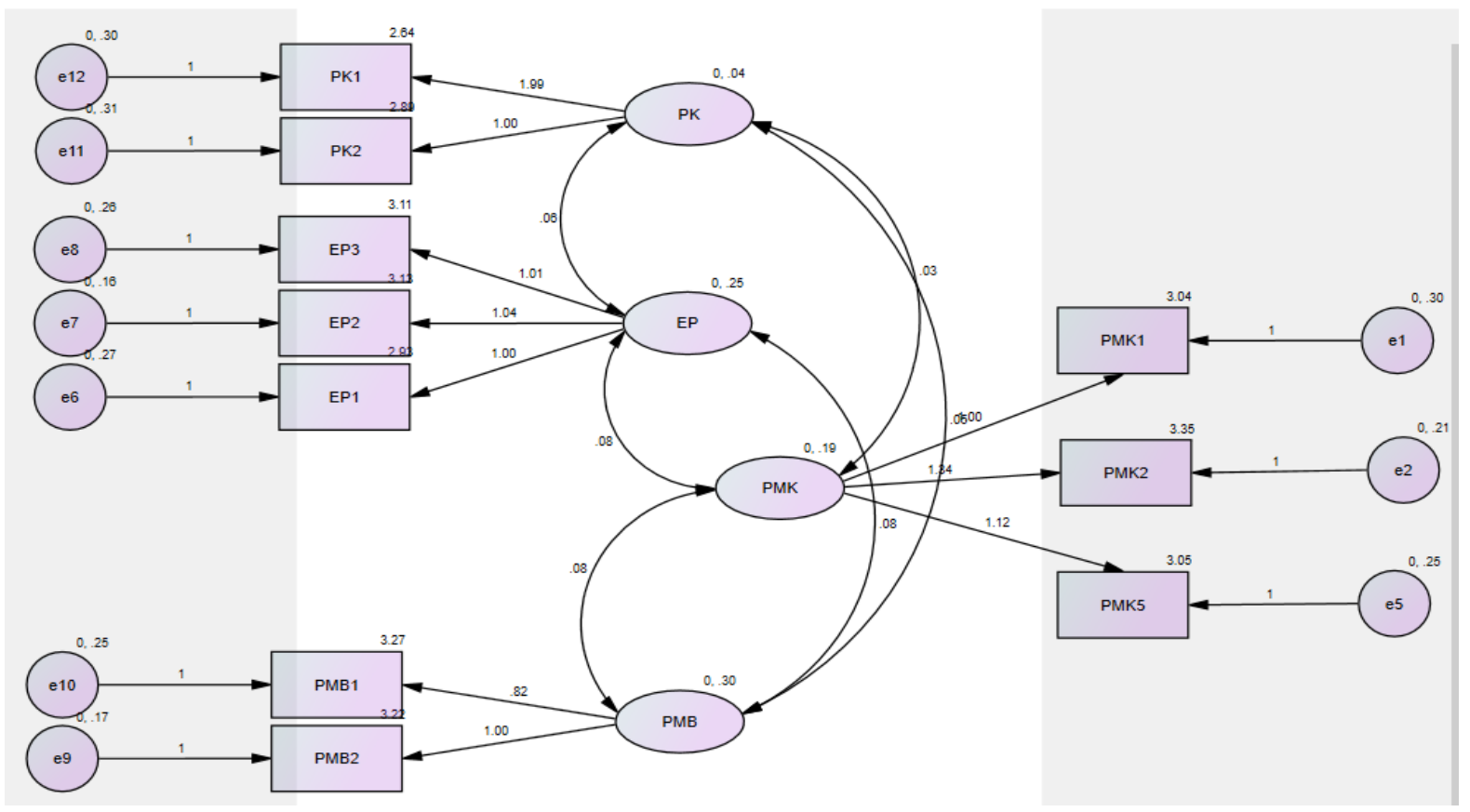

\section{Gambar 2}

Model Structural Equation Model (SEM)

Sumber : Data diolah peneliti tahun 2020 dengan program AMOS versi 24

Dari Model Structural Equation Model (SEM) pada gambar 2 terdapat 4 variabel yaitu pengetahuan keuangan (PK) dengan indikator PK1 dan PK2, elektronik perbankan(EP) dengan indikator EP1, EP2 dan EP3, perilaku mencari bantuan (PMB) dengan indikator PMB1 dan PMB2, dan perilaku manajemen finansial (PMK) dengan indikator PMK1, PMK2 dan PMK 5 (PMK 3 dan PMK 4 dihilangkan untuk mencapai nilai ideal CMIN/DF <2).

Hasil dari Path analysis ditunjukkan pada tabel 6 bahwa pada tabel tersebut mengindikasikan Critical Ratio test yang menunjukkan hanya EP $(* * *, \mathrm{P}<0,05)$ dan $\mathrm{PMB}(* * *, \mathrm{P}<0,05)$ yang memiliki hubungan yang kuat terhadap PMK. PK $(0,0 ; \mathrm{P}<0,05)$ tidak terindikasi memiliki hubungan signifikan dengan variabel Dependen (PMK). Hasil dari penelitian ini mendukung H2 dan $\mathrm{H} 3$ tetapi tidak mendukung H1. Hipotesis H2 dan H3 diterima dan H1 ditolak (gambar2).

Tabel 6

Tabel Result Structural Equation Model (SEM)

\begin{tabular}{|ll|llll|}
\hline & & Estimate & S.E. & C.R. & P \\
\hline PMK <--> & EP & .1 & .0 & 3.8 & $* * *$ \\
PMK <--> & PMB & .1 & .0 & 3.5 & $* * *$ \\
PK <--> & PMK & .0 & .0 & 2.4 & .0 \\
\hline
\end{tabular}




\section{Penilaian Kriteria Goodness-of-Fit Index}

Setelah data dinyatakan berdistribusi normal, maka model dapat diuji kesesuaiannya, dengan melihat nilai Goodness of Fit. Kriteria yang menjadi acuannya yaitu: Chi Square, CMIN/DF, CFI, IFI, TLI, RMSEA yang dihasilkan. Ukuran keseluruhan model SEM: Chi Square $=37,8 \mathrm{CMIN} / \mathrm{DF}=1,303 \mathrm{CFI}=0,983 \mathrm{IFI}=0,984 \mathrm{TLI}=0,974$ dan $\mathrm{RMSEA}=0,036$.

\section{Tabel 7}

Tabel Indeks Goodness Of Fit

\begin{tabular}{|l|l|l|}
\hline Kriteria & Hasil & Kesimpulan \\
\hline Chi Square & 37,8 & Baik \\
\hline CMIN/DF & 1,303 & Baik \\
\hline CFI & 0,983 & Baik \\
\hline IFI & 0,984 & Baik \\
\hline TLI & 0,974 & Baik \\
\hline RMSEA & 0,036 & Baik \\
\hline
\end{tabular}

\section{Tabel Correlation}

Dari tabel 8 dapat dilihat jika nilai AVE lebih besar dari squared correlation yang mana mengkonfirmasikan kondisi untuk discriminant validity yang terlihat hingga sejauh ini di mana pengukuran konstruksi tidak memiliki korelasi tinggi terhadap satu dan lainnya. Nilai Square root dari gambar AVE di tabel ditunjukkan pada diagonal dan nilai-nilai lainnya adalah correlation.

Tabel 8

Tabel Correlation

\begin{tabular}{|l|l|l|l|l|}
\hline & PMB & EP & PMK & PK \\
\hline PMB & 1.0 & & & \\
\hline EP & .3 & 1.0 & & \\
\hline PMK & .3 & .4 & 1.0 & \\
\hline PK & .5 & .6 & .4 & 1.0 \\
\hline
\end{tabular}

\section{Pembahasan dan Interprestasi Hasil Penelitian}

\section{H1: Pengaruh Pengetahuan Keuangan (X1) terhadap Perilaku Manajemen Keuangan (Y)}

Dari hasil uji pada tabel 4 Indikator dikatakan valid apabila Criteria Ratio (CR) $>1$,96. Dari indikator yang dimiliki Pengetahuan Keuangan yaitu: Deposito tetap bank komersial bebas resiko (PK1) berdasarkan penilaian responden, bahwa indikator tersebut berpengaruh terhadap Perilaku manajemen keuangan pada generasi milenial di Indonesia. Hal ini ditunjukan pada nilai C.R. indikator Deposito tetap bank komersial bebas resiko (PK1) sebesar 2,9. Nilai reliabilitas variabel pengetahuan keuangan $<0,5$ yaitu 0,42 maka 
dikategorikan bahwa Variabel dalam penelitian adalah tidak signifikan. Menurut teori Pengetahuan keuangan pribadi telah dinilai di berbagai negara dan disetujui apabila orangorang yang kekurangan pengetahuan tentang keuangan untuk menggunakan informasi baru yang disediakan untuk mereka di era baru yang mana informasi dibagikan secara terbuka. Generasi $Y$ atau generasi Milenial sudah harus membuat keputusan penting sejak dini, seperti melanjutkan pendidikan, membeli kendaraan, dan perumahan yang merupakan hal yang sangat penting untuk keuangan masa depan mereka (Killins, 2017). Hasil penelitian tidah sesuai dengan teori maka dinyatakan bahwa Pengetahuan keuangan tidak memiliki pengaruh secara signifikan terhadap perilaku manajemen finansial generasi milenial di Indonesia karena banyak responden yang menyatakan tidak setuju dengan 2 indikator dari variabel pengetahuan keuangan, responden tersebut rata-rata berpendidikan SMU/SMK dan belum bekerja jadi tidak mengetahui perihal deposito dan Inflasi.

\section{H2: Pengaruh Perilaku mencari bantuan (X2) terhadap Perilaku Manajemen Keuangan (Y)}

Dari hasil uji pada tabel 4 Indikator dikatakan valid apabila Criteria Ratio (CR) $>1$,96. Dari indikator yang dimiliki Perilaku mencari bantuan yaitu: mencari nasihat dari teman-teman sebelum berinvestasi (PMB1) berdasarkan penilaian responden, bahwa indikator tersebut berpengaruh terhadap Perilaku manajemen keuangan pada generasi milenial di Indonesia. Hal ini ditunjukan pada nilai C.R. indikator mencari nasihat dari teman-teman sebelum berinvestasi (PMB1) sebesar 4,6. Nilai reliabilitas variabel Perilaku mencari bantuan $>0,5$ yaitu 0,86 maka dikategorikan bahwa variabel dalam penelitian adalah signifikan. Menurut teori Perilaku mencari bantuan mempengaruhi pada pengambilan keputusan yang terkait dengan kesehatan dan mempengaruhi perilaku manajemen keuangan (Bapat, 2019). Hasil penelitian sesuai dengan teori dan dinyatakan bahwa Perilaku mencari bantuan memiliki pengaruh secara signifikan terhadap perilaku manajemen finansial generasi milenial di Indonesia karena banyak responden yang menyatakan setuju dengan 2 indikator dari Perilaku mencari bantuan, responden tersebut rata-rata berpendidikan SMU - S3 dan sudah bekerja dan paham perihal Investasi.

H3: Pengaruh Elektronik perbankan (X3) terhadap Perilaku Manajemen Keuangan (Y) Dari hasil uji pada tabel 4 Indikator dikatakan valid apabila Criteria Ratio (CR) $>1,96$. Dari dua indikator yang dimiliki Elektronik Perbankan yaitu: kemudahan atau kenyamanan untuk melakukan Internet banking (EP2) dan mobile banking lebih menarik (EP3) berdasarkan penilaian responden, bahwa kedua indikator tersebut berpengaruh terhadap Perilaku manajemen keuangan pada generasi milenial di Indonesia. Hal ini ditunjukan pada nilai C.R. indikator kemudahan atau kenyamanan untuk melakukan Internet banking (EP2) sebesar 8,9 dan mobile banking lebih menarik (EP3) sebesar 8,7. Nilai reliabilitas variabel Elektronik perbankan $>0,5$ yaitu 0,86 maka dikategorikan bahwa variabel dalam penelitian adalah signifikan. Menurut penelitian Mulyana, Soeaidy, \& Taufiq (2019), perkembangan teknologi komunikasi dan informasi dalam bentuk media sosial juga telah membawa banyak dampak pada kehidupan sosial dan gaya hidup, terutama bagi generasi milenial. Dari hasil penelitian sesuai dengan penelitian diatas bahwa Elektronik perbankan memiliki pengaruh secara signifikan terhadap perilaku manajemen finansial generasi milenial di Indonesia. karena banyak responden yang menyatakan setuju dengan 3 indikator dari Perilaku mencari bantuan, 
responden tersebut rata-rata berpendidikan SMU - S3 dan sudah bekerja dan paham perihal Mobile Banking.

\section{KESIMPULAN}

1. Elektronik perbankan memiliki pengaruh secara signifikan terhadap perilaku manajemen finansial generasi milenial di Indonesia. karena banyak responden yang menyatakan setuju dengan 3 indikator dari Perilaku mencari bantuan, responden tersebut rata-rata berpendidikan SMU - S3 dan sudah bekerja dan paham perihal Mobile Banking.

2. Perilaku mencari bantuan memiliki pengaruh secara signifikan terhadap perilaku manajemen finansial generasi milenial di Indonesia karena banyak responden yang menyatakan setuju dengan 2 indikator dari Perilaku mencari bantuan, responden tersebut rata-rata berpendidikan SMU - S3 dan sudah bekerja dan paham perihal Investasi.

3. Pengetahuan keuangan tidak memiliki pengaruh secara signifikan terhadap perilaku manajemen finansial generasi milenial di Indonesia karena banyak responden yang menyatakan tidak setuju dengan 2 indikator dari variabel pengetahuan keuangan, responden tersebut rata-rata berpendidikan SMU/SMK dan belum bekerja jadi tidak mengetahui perihal deposito dan Inflasi.

\section{IMPLIKASI}

1. Bagi Praktisi di bidang keuangan

Menambahkan pengajaran dalam manajemen keuangan pribadi ke dalam kurikulum sekolah atau perguruan tinggi dapat meningkatkan level perilaku manajemen finansial, literasi keuangan dan mengurangi masalah yang terkait kualitas aset. Para manajer keuangan ataupun pengajar keuangan dapat mengambil keuntungan dalam pemanfaatan aspek teknologi atau elektronik perbankan untuk meningkatkan perilaku manajemen finansial.

\section{Bagi Manajer Keuangan}

Manajer Keuangan mampu menekan arus peredaran uang agar terhindar dari tindakan yang tidak diinginkan dan mampu menghubungkan perusahaan dengan pasar keuangan, di mana perusahaan dapat memperoleh dana dan surat berharga perusahaan dapat diperdagangkan. Manajer keuangan mampu memilah anggaran yang akan di keluarkan untuk perusahaan maupun untuk karyawan dan harus memusatkan perhatian pada berbagai keputusan investasi dan pembiayaan, serta segala hal yang berkaitan dengannya.

\section{Bagi Investor}

Untuk mengurangi perilaku kurang nya tanggung jawab dalam manajemen keuangan pada golongan dewasa muda, Bank dapat mengadakan acara-acara yang dapat menciptakan ketertarikan di antara segmen untuk terlibat dalam pengembangan perilaku manajemen finansial. Dengan meningkatnya penting nya dalam perilaku mencari bantuan, bank perlu mengadopsi pendekatan konsultatif daripada pendekatan transaksi.

\section{SARAN}


Berdasarkan kesimpulan dan keterbatasan penelitian yang ada, maka saran yang dapat diberikan untuk penelitian selanjutnya adalah peneliti membuat penelitian dengan lebih banyak indikator agar hasil dapat lebih optimal.

\section{DAFTAR PUSTAKA}

Amalia Nusron, L., Wahidiyah, M., \& Setyo Budiarto, D. (2018). Antecedent Factors of Financial Management Behavior: An Empirical Research Based on Education. KnE Social Sciences, 3(10), 437. https://doi.org/10.18502/kss.v3i10.3146

Bapat, D. (2019). Exploring Antecedents to Financial Management Behavior for Young Adults. Journal of Financial Counseling and Planning, 30(1), 44-55. https://doi.org/10.1891/10523073.30.1.44

Baptista, G., \& Oliveira, T. (2017). Why so serious? Gamification impact in the acceptance of mobile banking services. Internet Research, 27(1), 118-139. https://doi.org/10.1108/IntR10-2015-0295

Bayuk, J., \& Altobello, S. A. (2019). Can gamification improve financial behavior? The moderating role of app expertise. International Journal of Bank Marketing, 37(4), 951-975. https://doi.org/10.1108/IJBM-04-2018-0086

Erawati, N. (2016). Pengaruh Literasi Keuangan, Pembelajaran Di Perguruan Tinggi, Dan Pengalaman Bekerja Terhadap Perilaku Keuangan Mahasiswa Fakultas Ekonomi Universitas Negeri Surabaya. Jurnal Pendidikan Akuntansi (JPAK), 5(1), 1-7.

Federal Reserve Board. (2016). Mobile Banking and Mobile Payments in the U.S., Board Of Governors of the Federal Reserve System. Federal Reserve Report, (March), 70. Retrieved from http://www.federalreserve.gov/econresdata/mobile-devices/files/mobile-devicereport-201203.pdf

Killins, R. (2017). The Financial Literacy of Generation Y and the Influence That Personality Traits Have on Financial Knowledge: Evidence from Canada. Financial Services Review, 26(2), 143.

Letkiewicz, J., Robinson, C., Domian, D. L., \& Uborceva, N. (2018). Behavioral and Wealth Considerations for Seeking Professional Financial Planning Help. SSRN Electronic Journal, 25, 105-126. https://doi.org/10.2139/ssrn.2666727

Lim, H. N., Heckman, S. J., Letkiewicz, J. C., \& Montalto, C. P. (2014). Financial stress, selfefficacy, and financial help-seeking behavior of college students. Journal of Financial Counseling and Planning, 25(2), 148-160.

Mulyana, D., Soeaidy, M. S., \& Taufiq, A. R. (2019). Millennial urban generations: Does become "A current generation" shift their attention to financial literacy? Malaysian Journal of Consumer and Family Economics, 22, 19-27.

Porto, N. (2014). Finacial literacy, overconfidence and financial advice seeking. 70(4), 78-88. 
Rasuma Putri, N. M. D., \& Rahyuda, H. (2017). Pengaruh Tingkat Financial Literacy Dan Faktor Sosiodemografi Terhadap Perilaku Keputusan Investasi Individu. E-Jurnal Ekonomi Dan Bisnis Universitas Udayana, 9, 3407. https://doi.org/10.24843/eeb.2017.v06.i09.p09

Sharon, Al. (2015). Understanding the Millennial Generation. Journal of Financial Service Professionals, 69(6), 11-14. Retrieved from http://eds.a.ebscohost.com.laureatech.idm.oclc.org/eds/pdfviewer/pdfviewer?sid=0a0336d0 -b8da-410d-a5b3-7e42fa4cbe86@sessionmgr4004\&vid=1\&hid=4210

Sundarasen, S. D. D., Rahman, M. S., Othman, N. S., \& Danaraj, J. (2016). Impact of financial literacy, financial socialization agents, and parental norms on money management. Advanced Science Letters, 22(12), 4312-4315. 